\title{
The role of security in the presence of children in public spaces of Shandiz City
}

\section{El papel de la seguridad ante la presencia de niños en los espacios públicos de la ciudad de Shandiz}

\section{Fatemeh Daneshvar Anbaran}

Ph.D. Student, Department of Geography, Mashhad Branch, Islamic Azad University, Mashhad, Iran

ORCID: https://orcid.org/0000-0002-1413-0995

\section{Katayoun Alizadeh}

Department of Geography, Mashhad Branch, Islamic Azad University, Mashhad, Iran ORCID: https://orcid.org/0000-0001-7875-0977

\section{Hamid Jafari}

Department of Geography, Mashhad Branch, Islamic Azad University, Mashhad, Iran ORCID: https://orcid.org/0000-0002-2007-562X

*Correspondence

Email: K-alizadeh@mshdiau.ac.ir
Cite as:

Daneshvar Anbaran, F., Alizadeh, K., \& Jafari. (2021). The role of security in the presence of children in public spaces of Shandiz City. Propósitos y Representaciones, 9 (SPE1), e879. Doi: http://dx.doi.org/10.20511/pyr2021.v9nSPE1.879

(C) Universidad San Ignacio de Loyola, Vicerrectorado de Investigación, 2021. 


\section{Summary}

Today, the urban environment is not only a space for daily living, but also should be a safe environment for the growth and excellence of the talents of citizens, especially children. Because children, as one of the most vulnerable groups, need safe spaces for their activities, this platform should be provided with proper planning by urban planners, geographers and thinkers of other sciences. The purpose of this study is to search for physical and social criteria in urban spaces in order to investigate the role of security in the presence of children in public spaces of the small town of Shandiz to increase the sense of security in these environments. This research is of applied type and its method is descriptive-analytical and the parametric statistical methods of Spearman correlation coefficient have been used to measure and analyze 370 citizen questionnaires designed according to Likert format using SPSS software. The statistical society of this study is 0-14 year old children in Shandiz. The results of this study show that the correlation coefficient for the two factors of safety and security are equal to 0.21 and 0.24 and positive, respectively, so the two factors of safety and security are directly related to the presence of children, and so the presence of children in public spaces of Shandiz city is affected by safety and security factors, which according to the citizens of Shandiz, public spaces in this city have a low and very low safety and security index.

Keywords: Child, Public Spaces, Child-Friendly City, Security, Presence Shandiz City.

\section{Resumen}

Hoy en día, el entorno urbano no es solo un espacio para la vida diaria, sino que también debe ser un entorno seguro para el crecimiento y la excelencia de los talentos de los ciudadanos, especialmente los niños. Debido a que los niños, como uno de los grupos más vulnerables, necesitan espacios seguros para sus actividades, esta plataforma debe contar con una planificación adecuada por parte de urbanistas, geógrafos y pensadores de otras ciencias. El propósito de este estudio es buscar criterios físicos y sociales en los espacios urbanos con el fin de investigar el papel de la seguridad en la presencia de niños en los espacios públicos de la pequeña localidad de Shandiz para incrementar la sensación de seguridad en estos entornos. Esta investigación es de tipo aplicado y su método es descriptivo-analítico y los métodos estadísticos paramétricos del coeficiente de correlación de Spearman se han utilizado para medir y analizar 370 cuestionarios ciudadanos diseñados según formato Likert utilizando el software SPSS. La sociedad estadística de este estudio son los niños de 0 a 14 años de Shandiz. Los resultados de este estudio muestran que el coeficiente de correlación para los dos factores de seguridad y protección es igual a 0,21 y 0,24 y positivo, respectivamente, por lo que los dos factores de seguridad y protección están directamente relacionados con la presencia de niños y, por tanto, la presencia de los niños en los espacios públicos de la ciudad de Shandiz se ve afectado por factores de seguridad y protección, que según los ciudadanos de Shandiz, los espacios públicos en esta ciudad tienen un índice de seguridad bajo y muy bajo.

Palabras clave: niño, espacios públicos, ciudad amiga de la infancia, seguridad, presencia ciudad de Shandiz. 


\section{Introduction}

Cities and their environments, like living things, need freshness and vitality to survive. The construction of fun and lively neighborhoods in cities requires the alignment of the characteristics of their places in responding to the needs of its residents, which can increase the continuous presence and improve the quality of life of residents, especially. Alleys, streets, playgrounds in small towns are important places for children's activities. In recent years, some attention has been paid to some parks, but They pay less attention to the quality of furniture and the security of the streets due to the increase in constructions in the cities So that in the end, these places do not have the necessary security and safety for children's daily activities. This type of design is increasing in developing countries, including Iran. With proper planning and design, these problems must be solved.

\section{Problem Statement}

What is certain is that urban spaces must be safe, usable and attractive for all sections of society (Ghorbani and Jalali, 2015: 2). According to the United Nations, about 54\% of people on Earth today live in cities.(paul \& sen, 2018: 142). While identifying the needs of children and ensuring the safety of children in public spaces is one of the most important tasks of urban planners. According to the statistical center of Iran in 2016, out of the total population of 13987 in Shandiz, 3872 people, equivalent to $27.6 \%$ are under 14 years old and children; However, field studies show that the infrastructure and facilities of public spaces in the small city of Shandiz are poor for children and are not properly located and distributed. The playgrounds and parks that exist throughout the city because of the distance from the children's place of residence and the location of some schools along the main streets, the lack of desirable and safe spaces for street walking, the existence of barren lands in the city and the inappropriate width of passages in some neighborhoods, lack of adequate light in The night has endangered the safety of children. Also, due to the special conditions of this summer and tourist-friendly city and its proximity to the capital of Mashhad, the presence of strangers in the city, heavy traffic due to vehicle traffic on the streets and passages, lack of lines, lack of proper bridges in some of the main streets of the city, the safety and traffic of children are endangered, so these issues have created concerns for children and families, and due to the development of the city, city managers and planners need to organize the public spaces of the city. Finally, due to the lack of security and safety of suitable places for children to participate in the community and noncompliance with the standards of child-friendly city in the design of the small town of Shandiz, leading research is necessary.

\section{Outline}

1. Highlights

2. Abstract

3. Keywords

4. 1. Introduction

5. 2. Literature review

6. 3. Research setting

7. 4. Results

8. 5. Discussion and implications

9. Concluding remarks 
10. CRediT authorship contribution statement

11. Acknowledgements

12. References

\section{Literature review}

The role of security in the presence of children in the public spaces of child-friendly cities around the world has been the subject of lots of researches, the excerpts of which are given below. UNICEF first introduced and recognized the Bendigo city of Australia as a child-friendly city and the first city that had all the aspects and characteristics of a child-friendly city in 2007. (Kiani and Ismailzadeh Kavaki, 2012: 55).

Table 1

Research Background.

\begin{tabular}{|c|c|c|c|c|}
\hline Row & $\begin{array}{l}\text { The Name of } \\
\text { the Scholar }\end{array}$ & $\begin{array}{l}\text { Year of } \\
\text { Research }\end{array}$ & Research Title & Research Result \\
\hline 1 & Jane Jacobs & 2019 & $\begin{array}{l}\text { Life and death in major } \\
\text { American cities }\end{array}$ & $\begin{array}{l}\text { In this book, Jane Jacobs, as a sociologist, } \\
\text { analyzes and comments on the impact of the } \\
\text { physical characteristics of the urban environment, } \\
\text { especially the role of streets in social interactions } \\
\text { and urban vitality and security, and the adaptation } \\
\text { of sidewalks for children's use. }\end{array}$ \\
\hline 2 & $\begin{array}{l}\text { Alizadeh and } \\
\text { Anbari }\end{array}$ & 2017 & $\begin{array}{l}\text { The role of defenseless } \\
\text { urban spaces in crime } \\
\text { occurrence } \\
\text { emphasis on the } \\
\text { district } 9 \text { parks of } \\
\text { Mashhad } \\
\text {. }\end{array}$ & $\begin{array}{l}\text { In this research, the role of physical and social } \\
\text { characteristics, in aggressive behavior shaping and } \\
\text { emerging in defenseless urban spaces and the } \\
\text { security level in these spaces was studied. The } \\
\text { results showed that in all studied indices the } \\
\text { significance level was equal to } 0.000 \text {. That shows } \\
\text { the significant and positive relationship between } \\
\text { the affective factors on security reduction in } \\
\text { parks and increasing crime occurrence. }\end{array}$ \\
\hline 3 & $\begin{array}{l}\text { Sajjadian et } \\
\text { al }\end{array}$ & 2016 & $\begin{array}{l}\text { The study of social } \\
\text { security feeling and its } \\
\text { affecting factors( Case } \\
\text { study: Izeh City) }\end{array}$ & $\begin{array}{l}\text { The results showed that between the satisfaction } \\
\text { level about the neighborhood, sense of belonging } \\
\text { and sense of security in the neighborhood has a } \\
\text { negative and significant relationship with the } \\
\text { feeling social insecure of citizens. }\end{array}$ \\
\hline 4 & $\begin{array}{l}\text { Vahdat, } \\
\text { Sajjadzadeh }\end{array}$ & 2016 & $\begin{array}{l}\text { The evaluation of the } \\
\text { role of urban arts in } \\
\text { increasing the level of } \\
\text { presence in public } \\
\text { spaces with emphasis } \\
\text { on urban graphic of } \\
\text { Hamedan people park. }\end{array}$ & $\begin{array}{l}\text { The results showed that the most impact of urban } \\
\text { graphic art in presence of urban places from the } \\
\text { citizens point of view and the public spaces users } \\
\text { is about the elements and physical indices and at } \\
\text { the second step is about the environmental, } \\
\text { semantic and social indices. }\end{array}$ \\
\hline 5 & Lotfi et al & 2014 & $\begin{array}{l}\text { The Investigation on } \\
\text { the feeling of security } \\
\text { in public spaces. } \\
\text { (Case study of Shiraz } \\
\text { metropolis) }\end{array}$ & $\begin{array}{l}\text { The results showed that the security feeling in the } \\
\text { public spaces of low-income districts with average } \\
\text { of } 12.74 \text { is more that the security feeling of } \\
\text { public spaces users average in middle class with } \\
11.56 \text { and high- income districts with } 12.42\end{array}$ \\
\hline
\end{tabular}




\begin{tabular}{|c|c|c|c|c|}
\hline 6 & Agha latifi & 2009 & $\begin{array}{l}\text { Adapting the } \\
\text { environment for } \\
\text { children's creativity }\end{array}$ & $\begin{array}{l}\text { He carefully studied the child's daily life and } \\
\text { identified his/her understanse about the } \\
\text { environment. Then with a comprehensive view } \\
\text { discovered the child's related environment and } \\
\text { finally presented some simple strategy for } \\
\text { adapting the living space for children. }\end{array}$ \\
\hline 7 & Shia & 2015 & $\begin{array}{l}\text { Preparing the city for } \\
\text { children }\end{array}$ & $\begin{array}{l}\text { This book is about the preparing the urban spaces } \\
\text { for children for the first time, and studying the } \\
\text { methods of interaction with children shows their } \\
\text { needs as the main social group and how to fulfill } \\
\text { their needs in cities. }\end{array}$ \\
\hline 8 & $\begin{array}{l}\text { Norwegian } \\
\text { Research } \\
\text { Council and } \\
\text { Consultant } C \\
\text { apgemini } \text { 'R } \phi \\
\text { rholt }\end{array}$ & 2019 & The Traffic Agent & $\begin{array}{l}\text { This is a program that allows children in Oslo to } \\
\text { report about their city security and simultaneously } \\
\text { are tracked by GPS. So the researchers could } \\
\text { identify and report the dangerous locations. }\end{array}$ \\
\hline 9 & Foster et al & 2014 & $\begin{array}{l}\text { Impact of fear of crime } \\
\text { on people walking }\end{array}$ & $\begin{array}{l}\text { By use of linear regression model, the impacts of } \\
\text { fear of crime on people walking in Australia were } \\
\text { studied and analyzed. The results showed that } \\
\text { with increasing the interventions and correct } \\
\text { decision making it could be overcome on } \\
\text { environment fear and increase the walking rates. }\end{array}$ \\
\hline
\end{tabular}

\section{Methodology}

\section{Research Method}

The present research is of applied type and in terms of research method is descriptive-analytical. In addition, obtaining the required information has been done through field and library data collection methods. The statistical population of this study is 0-14 years old children in Shandiz. According to the latest population and housing census in 2016, it was equal to 3872 people, which using the Cochran's formula, 370 citizens (children and parents) were selected for questioning. Then parametric statistics method was used to analyze the research data.

\section{Geographical Territory of Research}

Shandiz summer city is 1400 meters above sea level and is located at 59 degrees and 17 minutes longitude and 36 degrees and 23 minutes latitude. The city of Shandiz is located in Khorasan Razavi province in northeastern Iran, $12 \mathrm{~km}$ northwest of the mother city of Mashhad. This city is restricted from the north to Mianvelayat city and from the south to Neyshaboor city, from east to Torghabeh village and from west to Golmakan and Chenaran cities. It has an area of about 37,825 square kilometers (http://jahaniran.ir).

\section{Map 1}

Shandiz political situation in the country Iran and Khorasan Razavi province. 


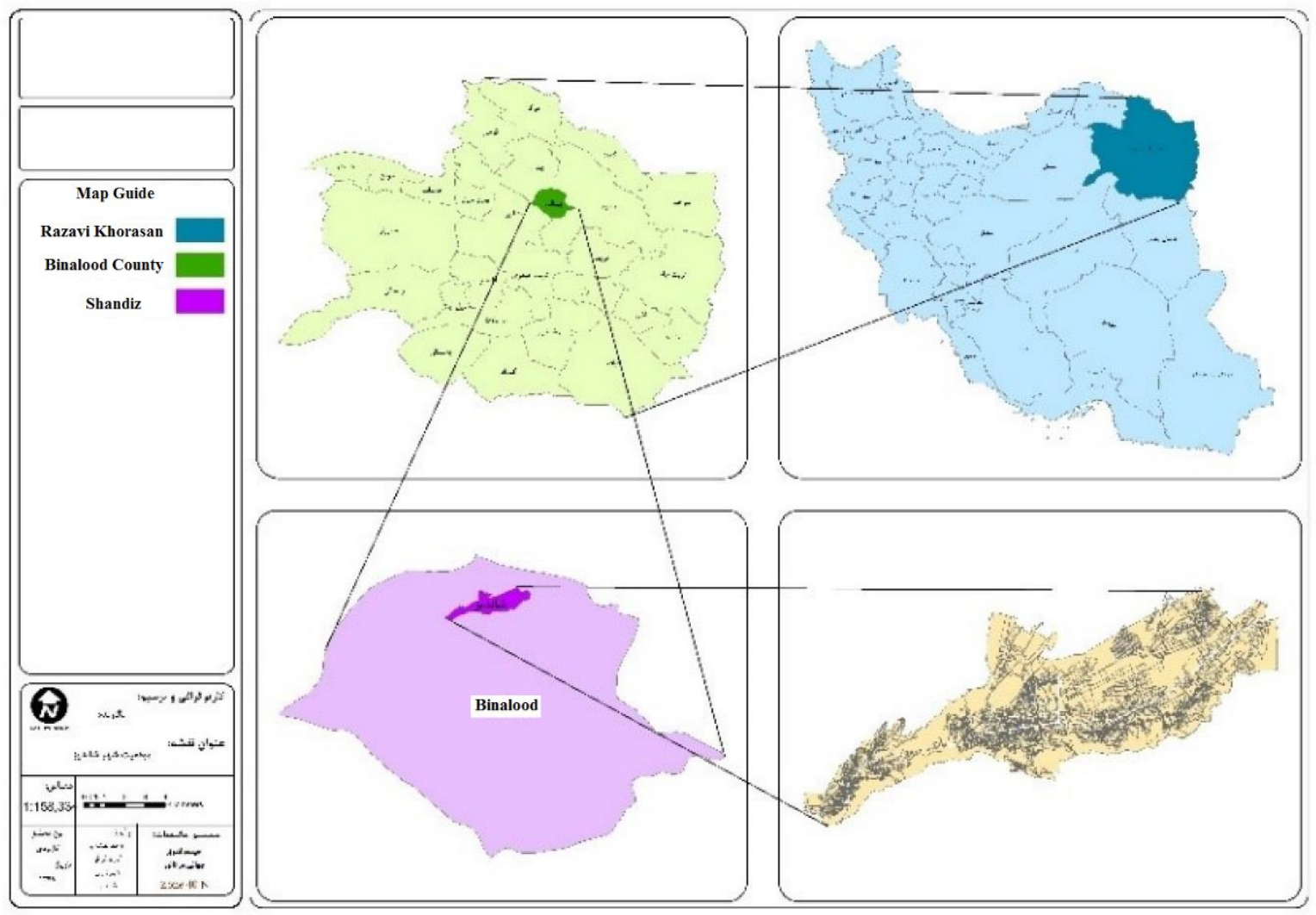

Source: Shandiz Municipality- Map and Cartography Unit- 2020

\section{Theoretical Foundations of Research}

\section{Child}

the meaning of child is every human less than 18 years of age, unless based on some countries law the legal age of children be considered less than 18. (http://www.unic-ir.org).

Child means any person under the age of 18 , unless the legal age of the child is less than the legal age.

According to the definition of Iranian Encyclopedia of Moeen, a child means a small, minor and a person who has not reached the age of puberty (boy or girl) (Karbalaei et al., 2014: 60). In this study, according to the definitions mentioned, and the existence of available census statistics, a child is a human who is less than 14 years old.

\section{Urban Public Spaces}

In cities, spaces are a wide range of public to private spaces. In other words, each activity and behavior has its own privacy and territory, and in return, each space has its own privacy and territory. Simply, the spaces in the city can be divided into three categories in terms of how to use them: public spaces, semi-private spaces and private spaces (Rezqi et al., 2016: 96).

\section{Figure 1}

Division of spaces in the city 


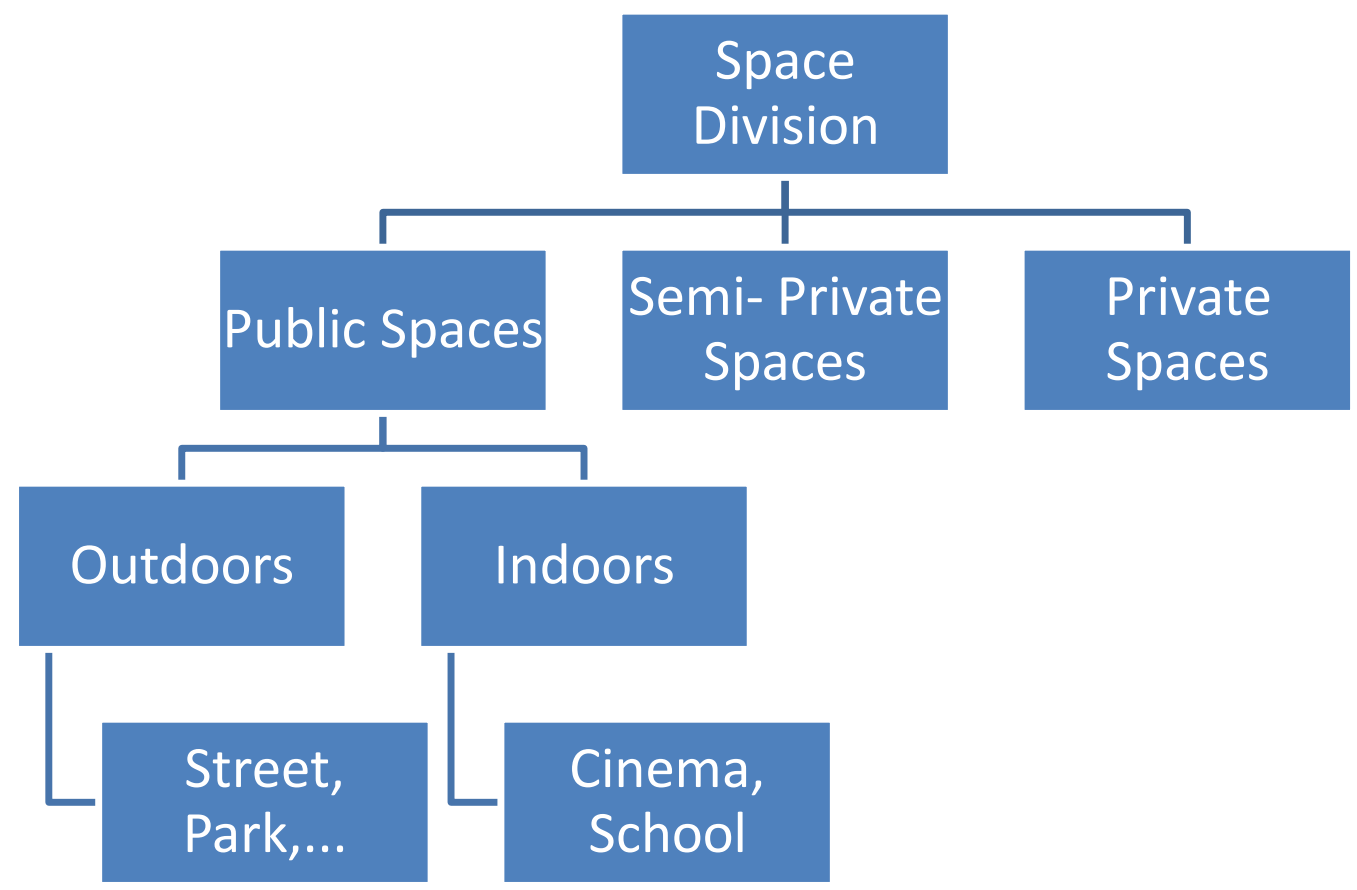

Source: Authors, 2020

According to the research topic, we will briefly deal with urban public spaces:

The term "public spaces" refers to spaces that are owned and used by the public (Deputy of Urban Planning and Development of the Tehran City Renovation Organization: 2020, 14). The general public has the right to enter and be present there without the need for control; such as streets, parks, squares, markets and mosques. (Nowruzi and Nastaran, 2014: 90)

\section{Theories of Child-Centered Urban Environments:}

Considering the importance of recognizing the important theories of child-centered urban environments, two perspectives of psychology and urban planning in relation to the child and the urban environment have been studied, which are summarized in the following tables. Among the psychological theories, the theories of Maslow, Ericsson and Piaget have a better ability to specify frameworks for environmental design.

\section{Urban Spaces Needed by the Child:}

The disorder of urban spaces and their non-adaptation to the needs of children, has caused a change in their activity patterns, lack of acceptance of mobility and movement and the occurrence of physical and health complications (Kharazmi et al., 2016: 2).

\section{Child's Favorite Urban Spaces:}

Attractive urban places for children are several groups, which are :1- Where there is a variety of games; Includes, Alleys, including hide and seek games, construction games, and games with water, snow, sand and gravel 2-Spaces where social activities with all age groups are possible 3Places that are well diversified in the environment and have a variety of facilities to use, including paths with different structures, Like dead end alleys and child parks (Hart, 1979, quoted by Saberi; Tahmasebizadeh, 2017: 7). 


\section{Child-Friendly City (CFC):}

Child-friendly cities have local authorities who take into account the demands and rights of children in accordance with the provisions of the Convention on the Rights of the Child in planning. (UNICEF Child Friendly Cities and Communities Handbook, 2018:10).

\section{Fig 2}

The structure cycle of a child-friendly city

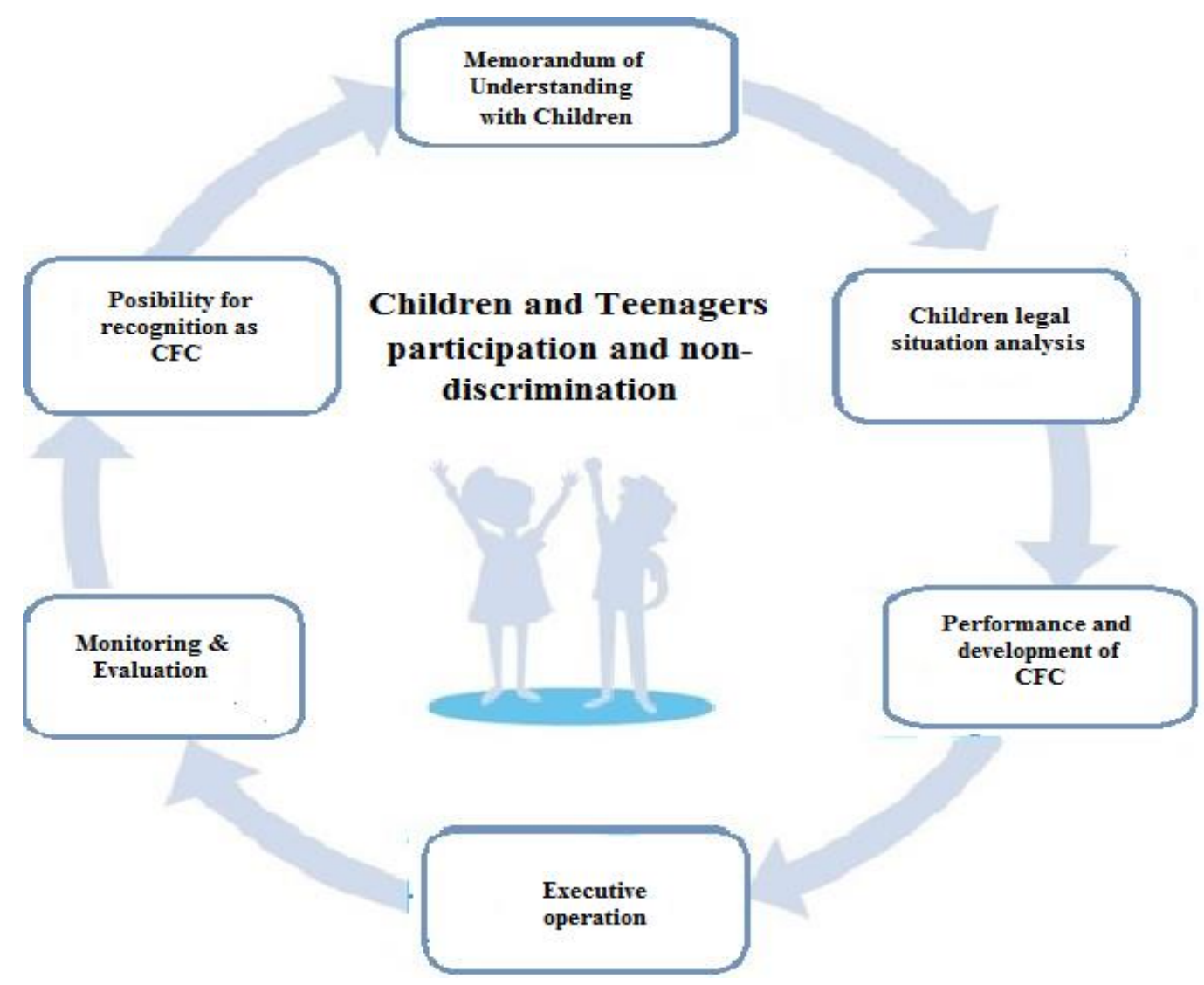

Source: (Louis Tiwant: 2018, 16) \& (UNICEF: 2018,23

\section{Attendance}

In general, presence in a place can be measured as the intensity of referring to that place in a specific time period and the length of stay in each visit (Khomberi, 2013: 106).

\section{Security and Safety}

The security means not worrying. It is to have a sense of peace and confidence (Mandel, 2000: 44). The safety refers to the cases and conditions of places that if their desired conditions are not met, the occurrence of accidents is inevitable and the dangers potentially and actually threaten 
the lives and property of those present, passers-by and observers. Safe urban space in its full sense includes environments in which both of the above components are present (Kelly \& Crabtree, 2009: 56).

\section{The Role of Security in the Presence of Children}

By being present in space, man seeks to make his existence meaningful and gain a foothold in space and time. By being present in space, man seeks to reveal and perceive meanings, and thus to social and purposeful life is reached (Schulz, 2010, pp. 2-4)

\section{Urban Security Indicators}

The safety and presence of children in urban spaces is affected by several components that can be examined at three levels: individual, physical and socio-cultural:

- Individual: Recognizing the characteristics and needs of the child, his perceptions and experiences of urban spaces, etc.

- Socio-cultural: values and policies of society and the role of social groups and institutions in the formation of urban spaces;

- Physical spatial: Physically appropriate city spaces;

At the physical level, how children relate to urban environments, criteria for optimal environments for children, and strategies for adapting the city to their presence are examined.(Kharazmi et al., 2016: 57).

\section{Figure 3}

Urban security indicators from three dimensions of function, body and environment.

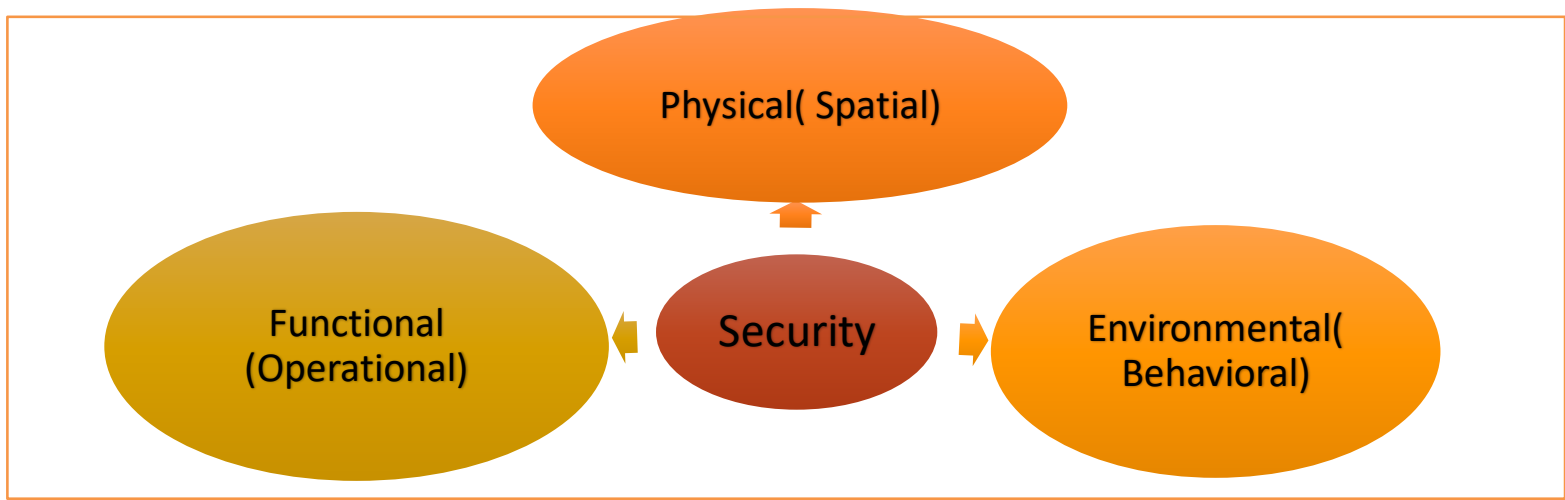

Source (Rafieian; Khodai, 2010: 191).

In urban environments, physical factors play the most roles in increasing or decreasing the feeling of security. Usually the most important effect of these factors is to reduce or increase public supervision. In addition, the physical elements of urban space can increase the feeling of security by creating a barrier against potential sources of danger (Alizadeh, 2017: 2).

- Making public places in cities safer for non-residents;

- Increase the skills of infants to deal with insecurities to better communicate with people؛ 
(Habibi; Hejazi: 2015: 40).

\section{Results}

\section{Review of the Studied Indicators}

\section{Safety}

Factors such as flooring of children and teenagers' playgrounds, floor coverings of park passages and stairs, and safety of benches, electric light poles, etc. are effective in the safety of public spaces in Shandiz city.

\section{Chart 1}

The indicator distribution of satisfaction about security of playground for children and teenagers.

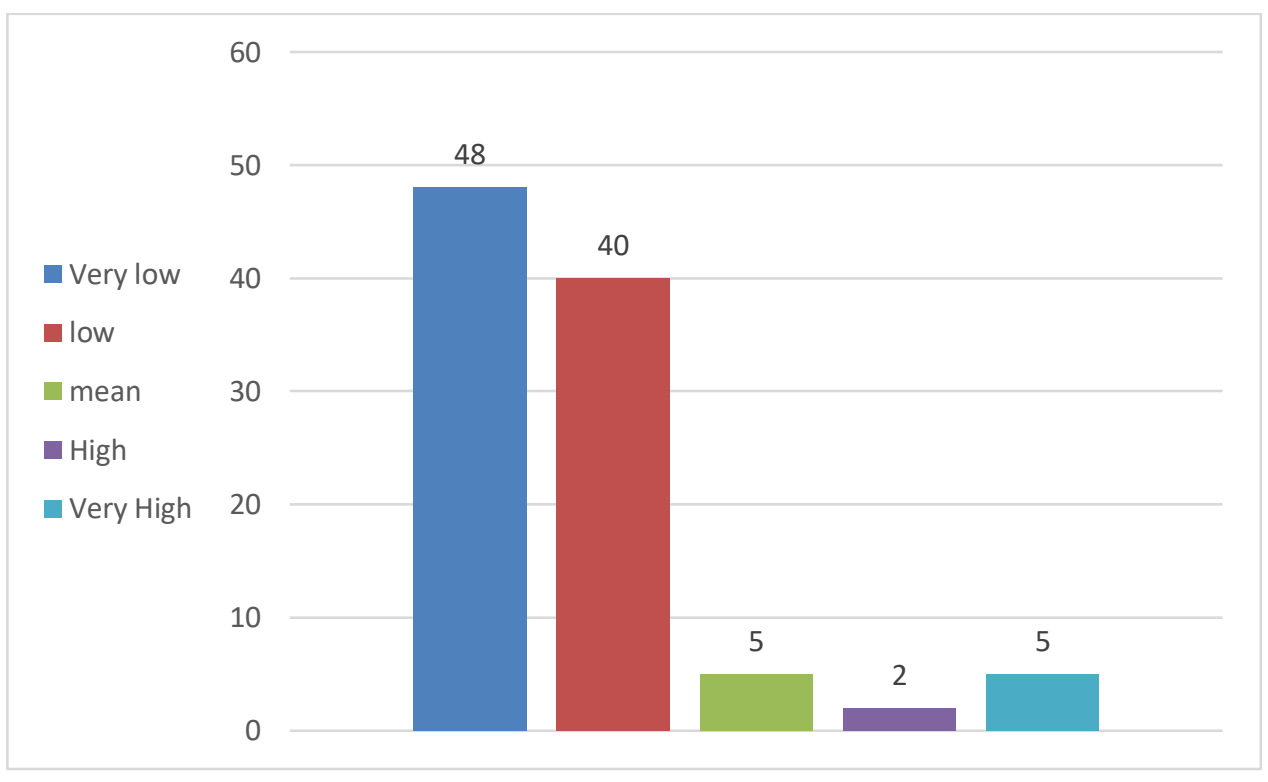

Table 5

The level of satisfaction from the indicator of being secure the playground for children and teenagers.

\begin{tabular}{|l|c|c|c|}
\hline Indicator & Comments & Frequency & Frequency Percent \\
\hline $\begin{array}{l}\text { How much do you } \\
\text { think the } \\
\text { playground for } \\
\text { children and } \\
\text { teenagers is safe? }\end{array}$ & Very low & 176 & 48 \\
\cline { 2 - 4 } & Low & 149 & 40 \\
\cline { 2 - 4 } & Hean & 18 & 5 \\
\cline { 2 - 4 } & Very High & 9 & 5 \\
\hline
\end{tabular}




\begin{tabular}{|c|c|c|c|}
\hline & Sum & 370 & 100 \\
\hline
\end{tabular}

According to Table 5 and Chart 1, most citizens (48\%) evaluate children and teenagers' playgrounds as very lowly safe and secure for them.

\section{Chart 2}

The distribution of the indicator of satisfaction from the safety of floor, pathways and stairs covering in public spaces.

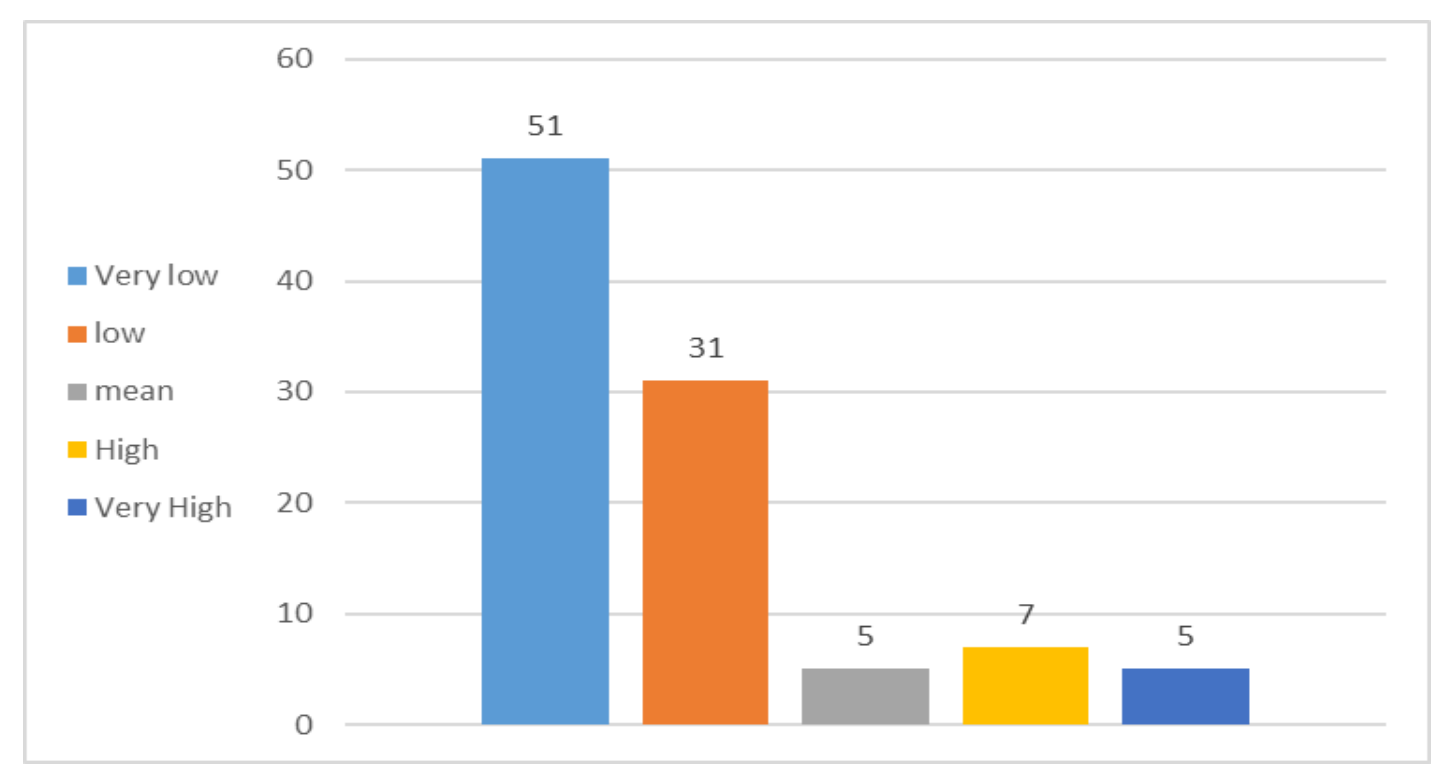

Table 6

The level of satisfaction from the indicator of safety for floor, pathways and stairs coverings in public spaces.

\begin{tabular}{|l|c|c|c|}
\hline Indicator & Comments & Frequency & Frequency Percent \\
\hline $\begin{array}{l}\text { How do you evaluate the } \\
\text { covers of floor and pathways } \\
\text { and stairs of public spaces } \\
\text { safety for children, elderly and } \\
\text { disabled persons? }\end{array}$ & Very low & 188 & 51 \\
\cline { 2 - 4 } & Low & 115 & 31 \\
\cline { 2 - 4 } & High & 20 & 5 \\
\cline { 2 - 4 } & Very High & 20 & 7 \\
\cline { 2 - 4 } & Sum & 370 & 100 \\
\hline
\end{tabular}

According to Table 6 and chart 2, most citizens (51\%) consider the floor, passages and stairs coverings of public spaces to be very lowly safe for children, the elderly, the disabled, etc.

\section{Chart 3}


The distribution of indicator of satisfaction from the benches, electric light poles, drinkings etc. safety for all groups.

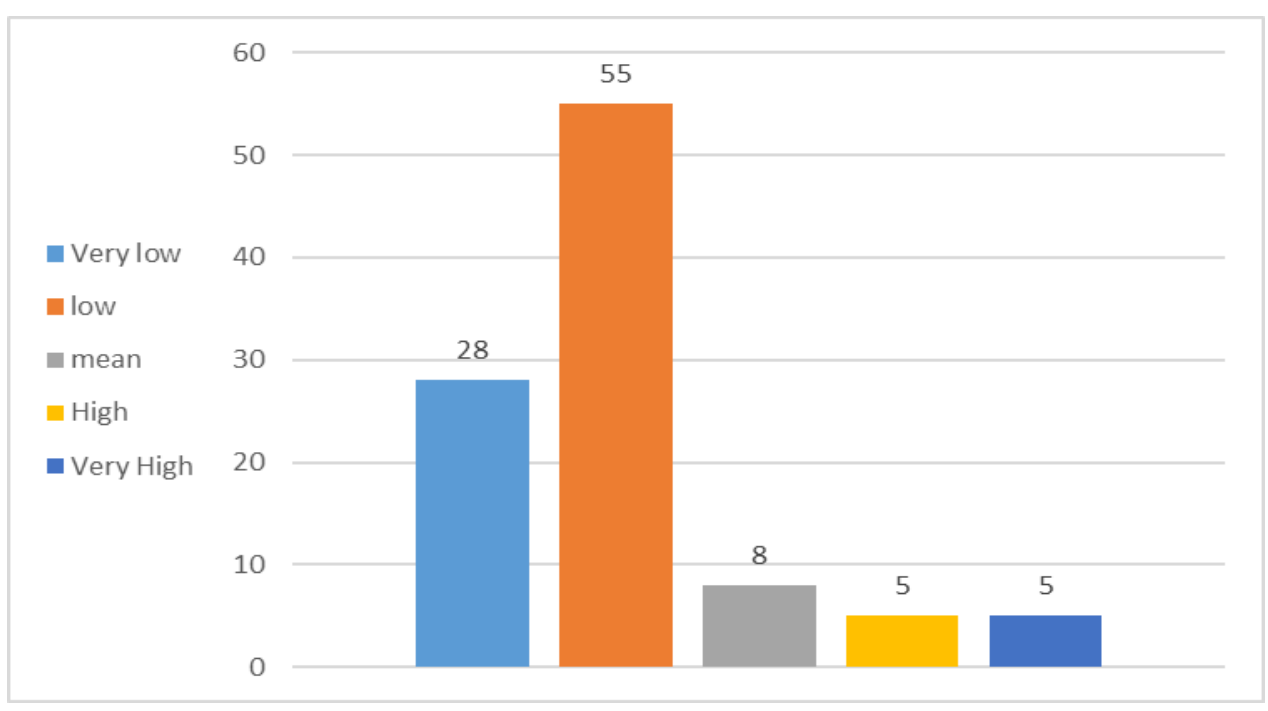

Table 7

The level of satisfaction about the indicator of bencheds, electric light poles, drinkings, etc. safety for all groups.

\begin{tabular}{|c|c|c|c|}
\hline Indicator & Comments & Frequency & Frequency Percent \\
\hline $\begin{array}{c}\text { How much do } \\
\text { you evaluate the } \\
\text { safety of benches, } \\
\text { poles, drinkings, } \\
\text { etc. for all groups } \\
\text { users of this } \\
\text { facility? }\end{array}$ & Very low & 102 & 28 \\
\cline { 2 - 4 } & Mean & 204 & 55 \\
\cline { 2 - 4 } & Hery High & 18 & 5 \\
\cline { 2 - 4 } & Sum & 370 & 100 \\
\hline
\end{tabular}

According to Table 7 and chart 3, most citizens (55\%) evaluate benches, light poles, drinking fountains, etc. to a lowly safe for all user groups.

\section{Security}

Factors such as places out of sight, secluded places, the absence of criminals, etc., and the lighting of public spaces at night are effective in the security of public spaces in the city of Shandiz. Children need to be safe in space because they are more vulnerable than other age groups.

most citizens $(50 \%)$ believe that there are a lot of places in public spaces that are out of the public eye and induce a sense of fear

\section{Chart 4}


The distribution of the indicator of existence of the places in public spaces where induce fear?

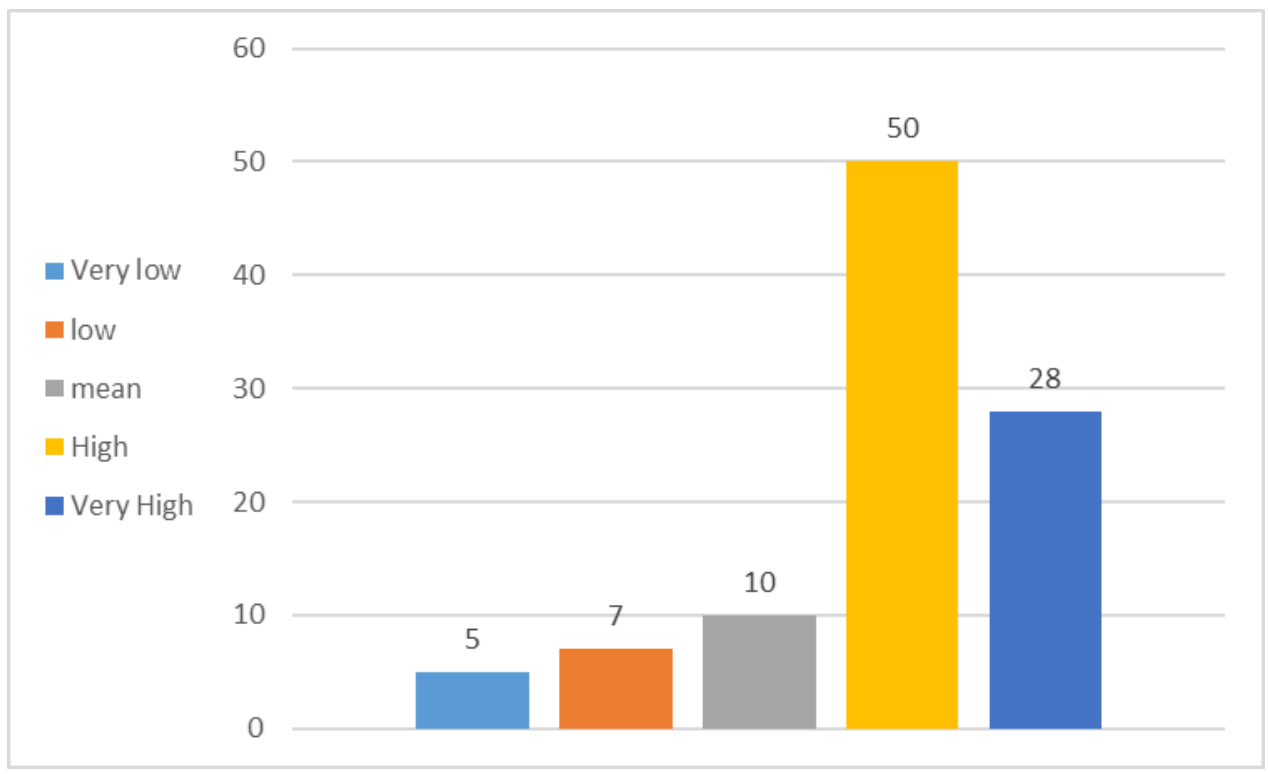

Chart 5

The distribution of the indicator of existence of secluded places in public spaces.

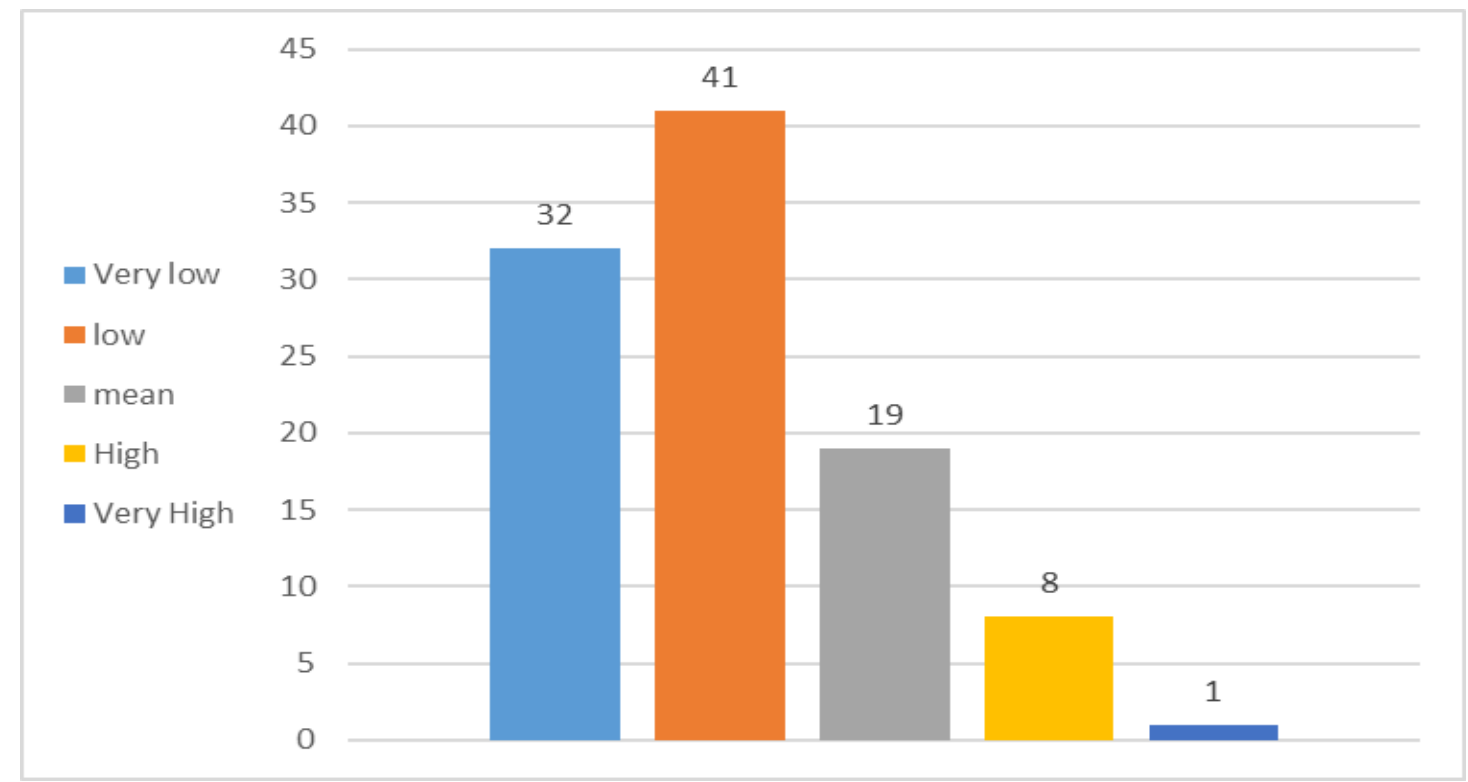

most citizens (53\%) are of the opinion that there are many secluded places and cozy corners in public spaces where it is possible to do criminal.

\section{Chart 6}

the distribution of the indicator of peace of mind about the lack of criminals. 


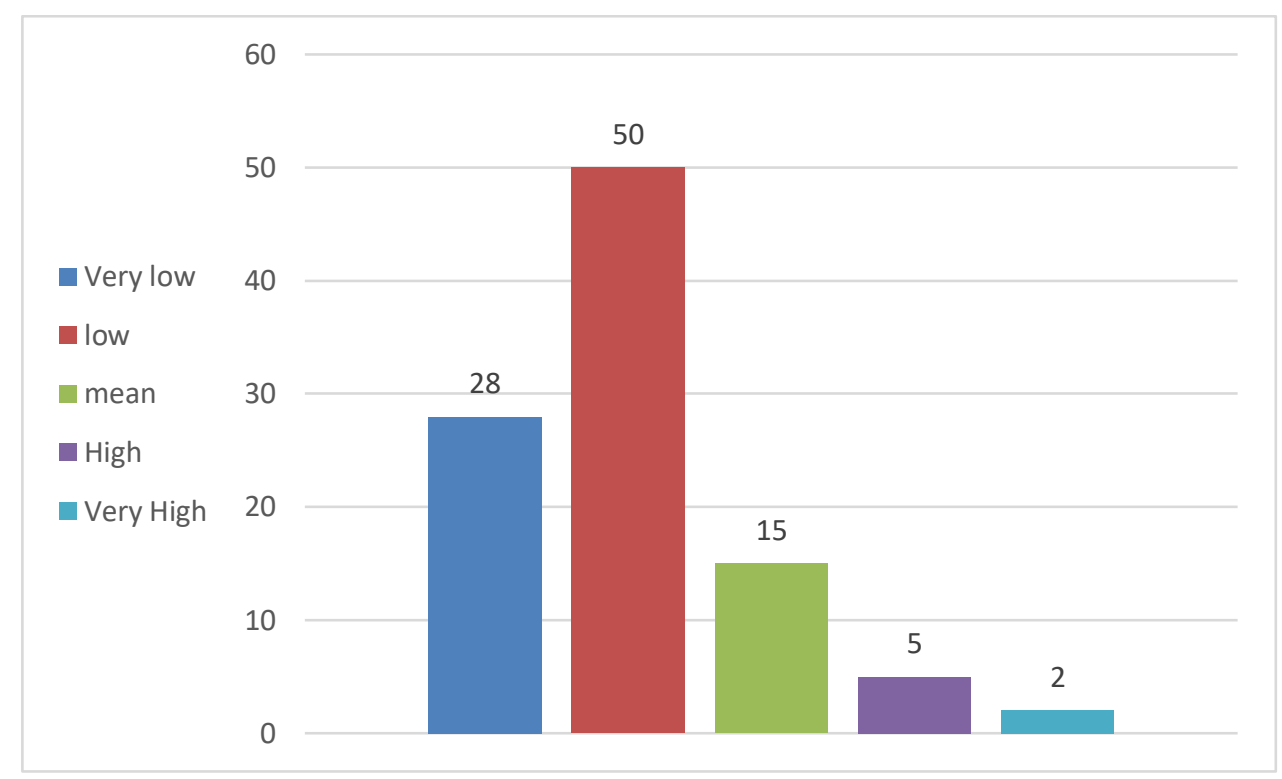

most citizens (48\%) are less satisfied with the peace of mind based on the absence of criminals, addicts, etc. when having fun in public spaces.

\section{Chart 7}

The distribution of indicator of satisfaction from security feeling at night in public spaces.

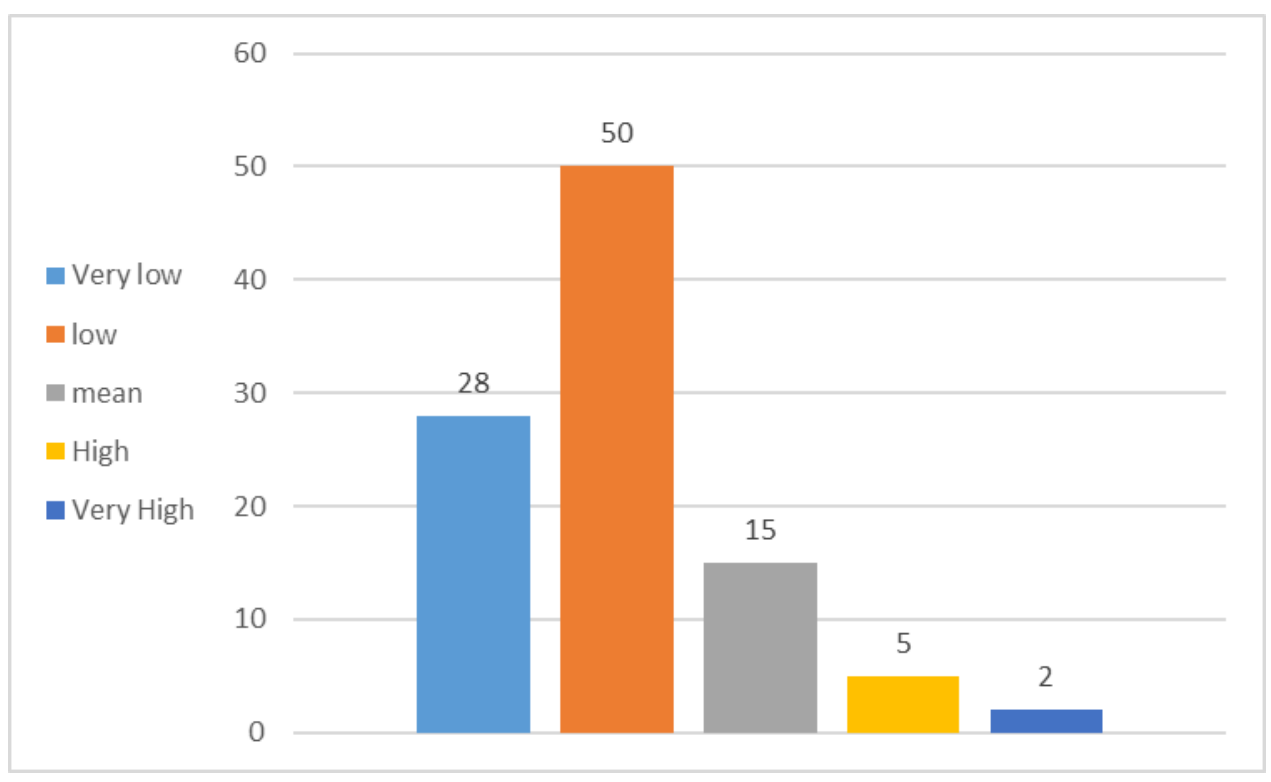

most experts (50\%) are less satisfied with the lighting of public spaces at night and feel safe.

Therefore, according to the citizens, it can be concluded that:

Attention to the two criteria of security and safety is considered low and very low in Shandiz city.

In order to evaluate the normality of the variables, Kolmogorov-Smirnov and Shapiro-Wilk tests were used, which are given in the following table:

the significance level for all variables is less than 0.05 , so it can be said that the variables are not 
normal. Therefore, non-parametric tests should be used.

The results of this test are presented in the table below:

the level of significance for the relationship between safety and attendance is less than 0.05 , so there is a relationship between safety and attendance of children. Also, the value of correlation coefficient is equal to 0.210 and positive, so there is a positive and significant relationship between safety and presence of children. The value of the significant level for the relationship between safety factors and the educational dimension is less than 0.05 , so there is a relationship between these two. In addition, the value of correlation coefficient is equal to 0.034 and is positive.

Therefore, we can say with $95 \%$ confidence:

Safety is effective in increasing the presence of children in public spaces in the city of Shandiz.

Also, to investigate the effect of security factor in increasing the presence of children in public spaces of Shandiz, Spearman correlation coefficient has been used, which measures the relationship between security and increasing the presence of children in public spaces of Shandiz. The results of this test are presented in the table below:

the value of the significance level for the relationship between security and attendance is less than 0.05 , so there is a relationship between security and attendance of children. In addition, the value of correlation coefficient is equal to 0.240 and positive, so there is a positive and significant relationship between safety and presence of children. The value of the significance level for the relationship between security and access factors is less than 0.05 , so there is a relationship between these two. In addition, the value of correlation coefficient is equal to 0.085 and positive, so there is a positive and significant relationship between security and access dimension. The value of the significance level for the relationship between security factors and space elements is less than 0.05 , so there is a relationship between these two.

Therefore, we can say with $95 \%$ confidence:

Security is effective in increasing the presence of children in public spaces in Shandiz.

\section{Conclusions}

Today, urban spaces are not limited to the physical aspect and are studied in relation to the behaviors of users of those spaces. Therefore, public spaces should have sufficient potential to strengthen social cohesion, economic development and improve the quality of collective life. Healthy public spaces can be a favorable platform for solving problems (physical, sociocultural, ...) and the correct education of future generations and providing the conditions for the flourishing of the talents of the young generation. Therefore, according to what has been said, solution Suggestions are as follows:

\section{Ensuring the safety of public spaces}

2. Increasing the lights in the spaces to increase the security at night in the alleys and streets of the risky and central core and the old part of Shandiz city; 
3. Equipping parks and cozy corners of passages and sidewalks with tables and chairs on a children's scale for children's meetings and rest, etc .;

4. Pay special attention to the type of palling of public spaces in order to make the child feel more secure, for example, wooden fences or short walls covered with greenery, short shrubs are more interested with the children.

5. Appropriate separation of carriageway and pedestrian paths to increase pedestrian safety and construction of pedestrian bridges in wide streets; Especially on the routes where the tourist traffic is more;

6. Use of traffic slowing techniques such as speed bumps and paving of streets, pedestrian crossings, flashing traffic lights in the vicinity of children's traffic areas such as parks, children's play spaces, Shandiz Mosque, especially schools that are in busy the streets;

7. Proper locating for schools, especially kindergartens and primary schools to facilitate access and increase the safety of children and the possibility of safe and pedestrian access to these places that are a basic right of citizenship and an important principle in child-friendly cities;

8. Establishment of drinking water in appropriate number and quality around the public spaces of Shandiz city on a child scale

9. Educating children and familiarize them with the dangers that lurk in the public spaces of the city, such as training classes on how to cross the street and familiarity with traffic rules and traffic signs and warning signs (with symbolic and educational games in parks and schools);

10. The construction of a fence around the barren and cozy lands of the city, which is a place for wandering and disturbing addict people that causes terror to children and endangers their safety, especially girls, which is abundant in the new fabric of Shandiz.

\section{References}

Abdullahzadeh, A. (2018). Study of the function of security in historical contexts with the approach of a child-friendly city (Case study: Bala Kaft Bala neighborhood of Shiraz). Quarterly Journal of Urban Structure and Function Studies, 5(17), 156-167. (In Persian).

Alimardani, M.,;Sharghi, A., \& Mahdenshin, N. (2016). Investigating the role of security in the vitality and nightlife of urban public spaces. Two Quarterly Journal of Applied Arts. 18, 123-130.

Alizadeh, K. (2017). The role of defenseless urban spaces with emphasis on the park. Journal of Urban Planning Research, 8(29), 90-101.

Arsh Kavosh Research Institute. (2016). Social Security of Children in Public Spaces of the City, Publisher of Tehran Center for Studies and Planning. Deputy of Science and Technology, 1, 245-267.

Bemanian, M. R., \& Mahmoudinejad, H. (2010). Security and urban design. Second Edition. Heleh Publication.Tehran (In Persian).

Deputy of Urban Planning and Development, Tehran City Renovation Organization. (2020) 
Electronic Booklet of Hidden Wealth of Cities; Creation, financing and management of public spaces. Translator, Mousavi Khorshidi, Razieh. https://nosazi.tehran.ir (In Persian).

Ebrahimi, A. (2019). Redesign of Azerbaijan neighborhood of Tehran with the focus on effective indicators in child safety in urban space (child friendly environment. Mohammad Ebrahimi, Mehdi; Mohammadi, Hadiseh; Ramzi, Meysam, Abdi, Ali. Meysam. Quarterly Journal of Management and Accounting Studies, 50(1), 178-199.

Foster, S., Knuiman, M., Villanueva, K., Wood, L., Christian, H., \& Giles-Corti, B. (2014).'Does walkable neighbourhood design influence the association between objective crime and walking?". International Journal of Behavioral Nutrition and Physical Activity,11, 100-123.

Ghasemloui, S., \& Parisa, A. (2014). The effect of form, structure and green space in creating a sense of security in designing a child-friendly space. National Conference on Urban Planning, Architecture, Civil Engineering and Environment. https: // www.sid.ir (In Persian).

Hatami Abarqoui, H. (2002). Children's contribution to sustainable urban planning with emphasis on designing the centers of Abarkouh neighborhood. National Conference on Sustainable Development in Arid and Semi-Arid Areas.( In Persian)

Hejazi, S. M., \& Habibi, K. (2015). Examining urban design strategies to create a child-centered urban space. (Case study: Hamedan city). Environmental studies of Haft Hesar, 14(14), $34-56$.

Jacobs, J. (2014). Death and life of big American cities Persian translator, Hamidreza; Aflatooni Arezoo. Publisher. University of Tehran. Fifth Edition. (In Persian)

Kelly, E., \& Crabtree, D. (2009). The Built Environment: An Analysis Crime Prevention Through Environmental Design, Ball State University ،Muncie ،Indiana.

Kharazmi, O. A., Zarghani, Seyed, H., Johari, L., \& Pejmat, S. M. (2017). Assessing the potentials of Mashhad to become a child-friendly city with emphasis on play and green spaces - children's health. International Conference on Urban Planning and Management. https://profdoc.um.ac.ir. (In Persian).

Kharazmi, O. A. (2016). The project of determining the indicators of a child-friendly city and evaluating the areas of Mashhad based on it. Mashhad Islamic Council Research Center. (In Persian).

Khumberi, S. (2013). The effect of child-friendly city principles on promoting public presence. Azad University of Tehran Markaz. https://ganj.irandoc.ac.ir. (In Persian).

Kiani, A., \& Ismailzadeh Kwaki, A. (2012) Analysis and Planning "Child Friendly City (CFC) (from the perspective of children) Case Study: Quchan. Quarterly Journal of Bagh Nazar Research Center for Architectural and Artistic Research Nazar, 12(9), 90-99. (In Persian).

Lewis, T. (2018). A guide to child-friendly cities and local communities. (https://www.unicef.org/iran). United Nations Children's Fund (UNICEF) April 2018 
Liu, J., Nijkamp, P., Huang, X., \& Lin, D. (2017). Urban livability and tourism development in China: Analysis of sustainable development by means of spatial panel data. The journal of Habitat International. 68, 99-107.

Lotfi, S. (2014) A study of the feeling of security in public spaces (Case study of Shiraz metropolis). Journal of Urban Planning and Research, 5(19), 23-45. (In Persian).

Mandel, R. (2008). The changing face of national security, translator and publisher of the Research Institute for Strategic Studies, third edition, Tehran. (In Persian).

Ministry of Interior. (2018). Child-friendly cities; Principles of characteristics and strategic conditions for municipalities. Deputy of Affairs of Municipalities. Office of Urban Development Planning and Management. Organization of Municipalities and Rural Affairs of the country (In Persian).

Nowruzi, A., \& Nastaran, M. (2014). Children's play space planning, first edition, Isfahan Jahad-e-Daneshgahi Publications (In Persian).

Paul, A., \& Sen, J. (2018). Livability assessment within a metropolis based on the impact of integrated urban geographic factors (IUGFs) on clustering urban centers of Kolkata. Cities. 74, 142-150.

Rafieian, M., \&Khodaei, Z. (2010) Citizens and public urban spaces. Published by the Office of Development of Science Production. Tehran. (In Persian)

Ramlee Maimunah, O. (2015). Revitalization of Urban Public Spaces: An Overview. Procedia Social and Behavioral Sciences, 201, 22-29.

Rastegar, A. (2018). Child-friendly urban design guide. A case study of improving the quality of space beds in neighborhood units to school for children from 3 to 12 years old. Shahid Beheshti University. Library. sub.ac.ir (In Persian)

Rezghi, Maryam., \& Rezghi, K. (2016). Analysis of urban spaces. Aval va Akhar publications. Second edition. Tehran. (In Persian)

Riggio, E. (2002). Child friendly cities, Good governance in the best interests of the child. Journal of Environment Urbanization, 14(2), 45-58.

Saberi, H., \& Tahmasbi Zadeh, F. (2017). Child-friendly urban spaces, attitudes and indicators. Fifth Conference on Design; By providing executive and strategic solutions. Urban Management Quarterly, 34, 89-96.

Schulze, S., \& Moneti, F. (2007). The Child Friendly Cities Initiative. Proceedings of the Institution of Civil Engineers. Municipal Engineer, 160 (2), 77-81

Shia, I. (2012). Preparing the city for children, case study: Tehran, Cultural and Artistic Organization. Municipality, Shahr Publishing Institute, Tehran (In Persian). 